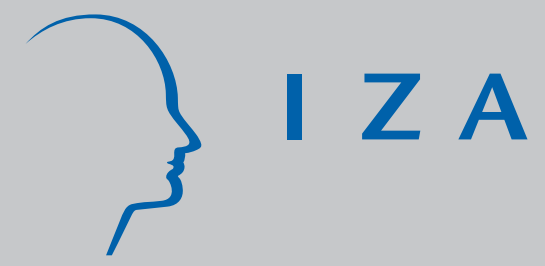

IZA DP No. 5565

Scarring Effects of the First Labor Market Experience

Oskar Nordström Skans

March 2011

Forschungsinstitut zur Zukunft der Arbeit Institute for the Study of Labor 


\title{
Scarring Effects of the First Labor Market Experience
}

\author{
Oskar Nordström Skans \\ IFAU, HECER, UCLS and IZA
}

\section{Discussion Paper No. 5565 \\ March 2011}

IZA

P.O. Box 7240

53072 Bonn

Germany

Phone: +49-228-3894-0

Fax: +49-228-3894-180

E-mail: iza@iza.org

\begin{abstract}
Any opinions expressed here are those of the author(s) and not those of IZA. Research published in this series may include views on policy, but the institute itself takes no institutional policy positions.

The Institute for the Study of Labor (IZA) in Bonn is a local and virtual international research center and a place of communication between science, politics and business. IZA is an independent nonprofit organization supported by Deutsche Post Foundation. The center is associated with the University of Bonn and offers a stimulating research environment through its international network, workshops and conferences, data service, project support, research visits and doctoral program. IZA engages in (i) original and internationally competitive research in all fields of labor economics, (ii) development of policy concepts, and (iii) dissemination of research results and concepts to the interested public.
\end{abstract}

IZA Discussion Papers often represent preliminary work and are circulated to encourage discussion. Citation of such a paper should account for its provisional character. A revised version may be available directly from the author. 
IZA Discussion Paper No. 5565

March 2011

\section{ABSTRACT}

\section{Scarring Effects of the First Labor Market Experience ${ }^{\star}$}

The paper studies the relationship between teenagers' first labor market experience and subsequent labor market performance using data on all Swedish youths graduating from vocational high schools in the recession years of 1991-94. Sibling fixed-effects combined with detailed data on high school programs, grades and work experience during high school are used in order to identify the causal long-run effects of post-graduation unemployment. The results show significant scarring effects resulting in higher risks of unemployment up to 5 years later. The results imply that poor labor market performance as a teenager result in persistent, but not permanent, negative effects.

JEL Classification: J64

Keywords: $\quad$ youth unemployment, scarring, state dependence, siblings

Corresponding author:

Oskar Nordström Skans

IFAU

Box 513

75120 Uppsala

Sweden

E-mail: oskar.nordstrom_skans@ifau.uu.se

\footnotetext{
* I thank Olof Åslund, Erika Ekström, Peter Fredriksson, Alan Krueger, Rafael Lalive, Eva Mörk and seminar participants at IFAU, SOFI, The Economic Council of Sweden, the 2004 EEA and the 2005 EALE/SOLE conferences for helpful comments and suggestions.
} 


\section{INTRODUCTION}

Young workers have higher entry rates into unemployment and higher exit rates out-of unemployment than older workers. As a result, young worker in general have relatively short unemployment spells which may suggest that youth unemployment is a harmless state requiring little attention from the policymakers. Nevertheless, most countries provide specific active labor market programs targeted at young workers. One possible rationale for policymakers' focus on youth unemployment is that some young workers may experience very long-term negative effects even from short unemployment spells, a phenomenon usually referred to as "state dependence" or "scarring".

There is also a large literature on the long-term consequences of unemployment. The results in most previous studies suggest that unemployment do indeed have persistent negative effects, at least for prime aged workers. Less is known about the consequences for young workers, even though scarring of young workers were the focus of early papers such as Ellwood (1982). The literature is plagued by the inherent difficulties facing econometricians due to problems with unobserved heterogeneity. The estimated effects will be larger than the true effects if workers differ in their underlying probability of being unemployed for reasons that we are unable to control for. Thus, separating the effects of unobserved heterogeneity from the causal effects of previous unemployment (i.e. the true scarring effect) is a fundamental problem in this literature.

This paper explores uniquely rich data containing detailed information on the characteristics for four full Swedish birth cohorts of young people in the process of entering the labor market through vocational high schools. The data cover aspects such as field of study, work-related educational performance, occupation specific labor market conditions, in school work experience, and family identifiers. We study the relationship between early 
labor market conditions and future outcomes using sibling fixed effects to remove the full impact of family background and the detailed individual information to control for differences between siblings. The identifying assumption is that the individual level covariates together with sibling fixed effects capture relevant persistent heterogeneity. The detailed individual level information have a large impact on the variable of interest in models without sibling fixed effects, but only a minor impact once sibling fixed effects are included. This suggests that the within-family-comparisons model is indeed a powerful tool for removing a potential bias stemming from individual heterogeneity. The results show that unemployment subsequent to graduation gives rise to significant "scars" that decline over time but which remain for at least 5 years after the initial unemployment experience. Further results suggest that both the incidence and duration matter, but that the impact of short spells vanishes more quickly than that of longer spells.

Since the sibling fixed effects model substantially reduces the sample size and the degrees of freedom, we also estimate models controlling for observable family background instead of the sibling fixed effects. This introduces a bias to the estimates but increases the precision which allows us to study the effects in smaller sub-samples. The results indicate that the long run effects of teenage unemployment are similar across various sub-groups defined by gender, ethnicity or business-cycle at the time of labor market entry.

The paper is structured as follows: Section II gives the institutional background and Section III defines the empirical model. Section IV describes the data and presents some descriptive statistics. Section $V$ shows the sibling fixed effects estimates and Section VI show sub-sample estimates. Section VII concludes. 


\section{BACKGROUND}

\section{$\underline{\text { Previous literature }}$}

Unemployment may have negative effects on future labor market performance for several different reasons: A first explanation has to do with human capital, either due to the forgone work experience during the unemployment spell or, perhaps more seriously, if people's skills actually deteriorate during a spell of inactivity as suggested by Edin and Gustavsson (2008). It is thus possible that (the market value of) skills acquired during high school may depreciate relatively fast unless the skills are used.

Second, if hiring takes place under uncertainty about worker productivity, employers may use previous unemployment spells as a screening device in their hiring process and thus prefer to hire workers with shorter unemployment histories. ${ }^{1}$

Third, institutions such as seniority rules that protect workers with long tenure on the expense of short tenured workers will give those receiving jobs early an advantage over those receiving their jobs later. This advantage may be important whenever a firm is hit by negative a shock later, which is consistent with results found in Eliason and Storrie, (2006).

Finally, very young workers' preferences for work and leisure may be influenced by their early experiences. Some support in this direction can be found in the literature on social interactions as in Kolm (2005) and Stutzer and Lalive (2003) which argue that the stigma of unemployment is affected by the labor market position of the reference group and that a smaller stigma may lower the outflow from unemployment. If unemployment per se causes teenagers to spend more time with other unemployed people, they may eventually have a

\footnotetext{
${ }^{1}$ In a survey of Swedish firms by Agell and Bennmarker (2002), employers confirm this idea. Further support is found in Eriksson and Lagerström (2004) who show that unemployed job seekers receive fewer job contacts than employed job seekers even after controlling for all information available to the employers using data from a Swedish "applicant data base".
} 
reference group with weaker labor force attachment. According to the above logic, this could reduce the stigma of unemployment and thus also the incentive to work.

The empirical literature on scarring or "state-dependence" dates back to the early 1980s with papers by Ellwood (1982), Corcoran (1982) and Heckman and Borjas (1980). The papers by Ellwood and Heckman and Borjas clearly identified the empirical obstacles that must be overcome in order to identify causal (or "true") state dependence. The basic problem is to separate causal effects from unobserved heterogeneity since any unobserved characteristics that causes a person to be unemployed at one point in time is likely to do so also in the future. There are basically three solutions that have been applied in the empirical literature: i) rely on observable characteristics ii) use aggregate unemployment as an instrumental variable or iii) make distributional assumptions regarding the unobserved component.

Ellwood (1982) studies US data from the NLSY and concludes that the effect of early non-employment on future employment probability is small but that the effect on wages is large. Corcoran (1982) studies a NLS sample of women and reaches similar conclusions regarding wages but also finds evidence of persistent negative employment effects. Heckman and Borjas (1980), in their empirical application, find little evidence of true state dependence. A recent study on US data is Mroz and Savage (2006) that use data from the NLSY in a dynamic model with lagged instruments and find significant effects four years after an unemployment spell on both annual earnings (approximately 1\% from 10 weeks of unemployment) and the unemployment probability (4\% from 10 weeks of unemployment). Evidence suggesting that unemployment may affect future wages through "implicit contracts" can be found in the paper by Beadry and DiNardo (1991) who show that wages are affected by the aggregate unemployment rate at the time of hiring. 
For the UK Arulampalam, Booth and Taylor (2000) used data from the British Houshold Panel Survey (BHPS) and a random effects specification finding evidence of state dependence in unemployment, a result confirmed by Arulampalam (2002) using a similar identification strategy. In addition she finds that the effects were smaller for workers under 25. Studies on British data that rely on observables for identification include Arulampalam (2001) that finds a 14\% earnings loss 3 years after an unemployment spell in the BHPS, Gregory and Jukes (2001) that uses administrative data and find a short-run effect of unemployment incidence and a long run effect of unemployment duration and Gregg (2001) using the National Child Development Survey (NCDS) who finds evidence of state dependence in unemployment, particularly for men. Gregg (2001) also uses aggregate unemployment as an instrument for individual unemployment which, surprisingly, generates larger estimates. Gregg and Tominey (2005) study the effects of male youth unemployment using the Brittish NCDS and find large persistent wage effects. Burgess, Propper, Rees and Shearer (2003) use a different approach and controls for aggregate unemployment and find negative effects for the non-skilled of entering the labor market in a cohort with high youth unemployment.

Evidence from other countries are scarce, Hämäläinen (2003) applies a correlated random effects model to Finnish data and finds evidence of short-term scarring effects, in particular for low-educated workers. Knights, Harris and Loundes (2002) use a similar method on Australian data finding evidence of scarring effects of unemployment. Muhleisen and Zimmerman (1994) applies a random effects probit to German data and find evidence of 
short run state dependence. Clark, Gorgellis and Sanfey (2001) also use German data and show that unemployment leads to long-lasting disutility effects, at least for men. ${ }^{2}$

Little other relevant evidence exists on Swedish data. Exceptions are Åslund and Rooth (2007) who find that refugee immigrants that where placed in municipalities with high unemployment rates performed worse at the labor market for a long period of time and Hansen and Lofstrom (2003) who study the dynamics of welfare receipt among immigrants and native Swedes.

Overall, the evidence suggests that scarring is a real phenomenon. ${ }^{3}$ On the other hand, the results suggest that the effects are smaller for young workers and, furthermore, estimates of scarring effects are likely to be upward biased if the observed covariates or distributional assumptions fail to appropriately control for individual heterogeneity.

The economic environment and institutions

The analysis of this paper is based on data on the cohorts graduating from Swedish high schools between 1991 and 1994. The cohorts are followed until the year 2001. This is the most turbulent period in the Swedish labor market since World War II, the consequences of the crisis were even worse than those induced by the recent global recession. The unemployment rate which had been below $5 \%$ since the 1960 s and was around $2 \%$ in the late 1980s suddenly increased to $10 \%$ in the early 1990 s (see Figure 1 ). The unemployment rate remained high until the late 1990s when it started to decline and by the year 2002 the

\footnotetext{
${ }^{2}$ There is also a potentially relevant literature on plant closings. A recent survey is provided by von Wachter (2009). An example on Swedish data is Eliason and Storrie (2006) who show that there are significant negative effects of plant closings that can be reinforced when the business cycle turns bad, even several years after the initial shutdown. However, it is not evident that evidence from plant closings can be generalized to other sources of unemployment, in particular those of entering groups.

${ }^{3}$ The main exceptions are the early papers by Ellwood (1982), for employment, and Heckman and Borjas (1980). However it should be noted that these papers, as pointed out in the papers themselves, use very small $(\mathrm{N}=364$ and 122$)$ and nonrepresentative samples, which suggests that not too much weight should be put on these empirical results.
} 
unemployment rate had declined to $5 \% .^{4}$ The time pattern for youth unemployment showed a similar time pattern as the overall unemployment rate, although at with much more pronounced swings due to the higher level. The 1990s also saw a rapid expansion of the proportion of the working aged population enrolled in education. As a result, the employment to population rates did not recovered as well as the unemployment rates after the recession, especially not for younger workers.

\section{[Figure 1]}

Our empirical model will account for the varying business cycle environment through year dummies. Furthermore, in a robustness analysis we will estimate separate effects separately for the cohort that graduated in 1991 when labor market conditions still were relatively decent in order to see how the estimated effects vary with the business cycle.

The Swedish educational system requires that all children start school during their $7^{\text {th }}$ year and attend 9 years of compulsory schooling. After finishing $9^{\text {th }}$ grade (during their $16^{\text {th }}$ year) most students choose to start high school. As an example, 85\% of those born 1973 received a high school diploma before the age of 20. High school students in Sweden are enrolled in one of several possible "programs". During the period of study (1991-94) the programs were standardized into three main categories: academic 3-year programs, academic 2-year programs and vocational 2-year programs. Most youths progressing to tertiary education came from the 3-year academic programs and these will therefore be excluded from our analysis. On some locations there was also a piloting scheme with vocational 3-year programs. ${ }^{5}$ Since the role of these programs mainly was as substitutes for the shorter vocational programs, they will be included in the analysis.

\footnotetext{
${ }^{4}$ The figure stops in 2004 due to a break in the series which has a large impact on measured youth unemployment.

${ }^{5}$ Due to a reform of the vocational programs in the early 1990s, all Swedish high school students graduating after 1994 received a 3 year long education that qualifies for university studies. However, this institutional change does not apply to the cohorts included in this study.
} 


\section{THE EMPIRICAL FRAMEWORK}

There are many reasons for why there may be an association between early unemployment and future labor market performance. Following Gregg (2001) we may summarize them as:

1. Individual heterogeneity: some people may be more prone than others to poor labor market outcomes due to persistent differences in preferences or abilities.

2. Labor market persistence: a young worker may become unemployed due to poor labor market conditions in the relevant region or occupation. The individual will be more likely to be unemployed in the future as well, if the conditions are persistent.

3. Scarring: Unemployment in itself may generate unemployment in the future either through firm discrimination, human capital depreciation, or other mechanisms.

More formally we can assume a two-period data generating model. In period 0 the worker enters the labor market and in period $t$ we measure the effects of unemployment in period 0 . Let $X_{i}$ be a vector of observed individual specific characteristics, and let $R_{i}$ denote an unobserved individual specific effect for individual $i$ having the effect $v_{\mathrm{t}}$ at time $t$. Let $A_{i t}^{j}$ be the labor market conditions faced by the individual at time $t$ at the labor market $j$ (e.g. defined by region and occupation). Allowing for scarring effects in period $t$ we get a model determining the unemployment of individual $i$ in period 0 (denoted by $U_{i 0}$ ) and the labor market performance (employment, unemployment, or wages) in period $t$ (denoted by $Y_{i t}$ ):

$$
\begin{aligned}
& U_{i o}=X_{i} \beta_{0}+\lambda_{0} A_{i o}^{j}+R_{i}+\varepsilon_{i o} \\
& Y_{i t}=X_{i} \beta_{t}+\lambda_{t} A_{i t}^{j}+\gamma_{t} U_{i o}+v_{t} R_{i}+\varepsilon_{i t}
\end{aligned}
$$


In our empirical applications of this equation, $t$ will range from 1 to 10 (at most). Our main identifying strategy uses sibling fixed effects $\left(\alpha_{i}^{S}\right)$ to proxy for the individual specific effect $v_{t} R_{i}$ and we estimate the equation: ${ }^{6}$

$$
Y_{i t}=X_{i} \beta_{t}+\lambda_{t} A_{i t}^{j}+\gamma_{t} U_{i o}+\alpha_{i t}^{S}+u_{i t} .
$$

Thus, the identifying assumption behind the sibling fixed effects estimates is that all differences between siblings that are correlated with both unemployment at time 0 and labor market performance at time $t$ are captured by the individual specific variables included in $X$, (i.e. such that $\operatorname{cov}\left(u_{i t}, U_{\mathrm{i} 0}\right)=0$ for all $\left.t\right)$.

We also estimate an "OLS-specification" where we proxy the unobserved individual component by observable family characteristics $\left(Z_{i t}\right)$ instead of the sibling fixed effect:

$$
Y_{i t}=X_{i} \beta_{t}+\lambda_{t} A_{i t}^{j}+\gamma U_{i o}+\phi_{t} Z_{i t}+\eta_{i t}
$$

This model can only be given causal interpretation if it can be argued that all differences between individuals that are correlated with both initial unemployment and subsequent performance are captured either by the observed individual specific information (the $X$ vector) or the observed family background variables (the $Z$-vector). The main reason for estimating the OLS model is that it greatly increases the sample size and thus the precision in the estimates. Since the identifying assumptions are stronger in the OLS specification, we will mainly use it to check for differences in estimates between different sub-samples.

The aim of the applied empirical models is to generate a situation where we are comparing two groups that are (conditionally) as similar as possible, where one group did become unemployed, and the other did not, and compare the subsequent outcomes of these two groups. The logic behind the model can be understood in the context of a standard

\footnotetext{
${ }^{6}$ One common method used in order to identify state dependence is to rely on distributional assumptions such as correlated random effects models. However, one drawback with this method is that the underlying assumptions are difficult to
} 
model of search frictions (see e.g. Pissarides 2000). Search frictions, empirically documented in e.g. Ridder and van den Berg (2003), imply that even identical individuals will end up in different states when first entering the labor market due to factors that can be treated as purely random. Thus, it should, in theory, be possible to identify scarring effects by conditioning on individual characteristics, given sufficiently good data. ${ }^{7}$ If, however, the identifying assumptions fail, we are bound to overestimate the true effect. We return to this issue in the concluding section.

\section{DATA AND DESCRIPTIVE STATISTICS}

The data used in this paper cover four entire cohorts of young individuals graduating from vocational and 2-year academic high school programs between 1991 and 1994. We exclude 3-year academic programs in order to minimize the impact of transitions into further education. We also require that the graduates are aged 18 or 19 (the normal ages).

\section{Data}

The general source of data is the IFAU database that combines data from various registers from Statistics Sweden and the National Labor Market Board. The original data sources are the high school examination registers (UREG) which contain information on grades and courses for all high school graduates, a longitudinal income register (LOUISE) that links family members to each other and contain information on demographics and socioeconomic factors, the employment register (RAMS) containing information on employment and

validate. Furthermore, since we specifically look at the effect of the initial state we only have one observation per individual in each regression, making it impossible to include individual-specific random effects.

${ }^{7}$ The use of sibling data in the literature on returns to education has been criticised by e.g. Griliches (1979) and Bound and Solon (1999) on concern that if indeed siblings are so alike, why do they end up with different education? In the current application the corresponding question would be "why do they end up in different initial states?" Ideally, the true answer is "due to matching frictions". 
earnings and an unemployment register (HÄNDEL) which contain information on spells of registered unemployment at public employment services.

Education and work experience. The individuals included in this study all graduate from i) vocational 2-year programs ii) theoretical 2-year programs or iii) the vocational 3-year pilot programs. The programs train students for specific occupations such as child care or auto repairs. Each student takes a set of courses, some of which are compulsory for all students in the program, and some of which are chosen by the student. ${ }^{8}$ Our data includes detailed information on course specific grades from which we construct three different variables: Overall grade point average $(G P A)$, field specific grade point average ( $F G P A)$ capturing the average grade in courses that are directly related to the occupational field of the program (e.g. "Construction" for the Construction workers program) ${ }^{9}$ and a dummy for students that either failed or received the grade 1 (out of 5) in any course (Failed).

By nature, high school graduates have very little labor market experience. However, we use information on labor earnings during the final complete calendar year in high school and a dummy for whether the student was employed in November during the same year. The idea is that these variables should capture both unobserved ability (e.g. in the form of motivation) and potential effects of in-school work experience (see e.g. Häkkinen, 2006).

\footnotetext{
${ }^{8}$ The selection of courses taken by each student is a complicated process: Many programs have different specific fields to which the students have to apply in advance, e.g. electricians can be either general electricians or specialised on telecommunication. In addition, some courses are chosen by the student; typically this choice is between a predetermined set of courses which may vary between schools.

${ }^{9}$ The FGPA is constructed from the data by looking at the courses most often taken by graduates of each program, excluding general courses such as Swedish and mathematics. The FGPA-variable is the average grade within the specific courses taken by each student. The ordinary GPA is used for the (few) students that did not take any field specific courses and for all students from the 3-year vocational programs in the piloting scheme since their field specific grades are missing in the data. In order to assess the robustness of our results we also estimate a model including only (18-year old graduates of ) the 2-year vocational programs.
} 
Demographic variables. A key set of background information refers to the parents of the graduates. In constructing these data, step-parents and biological parents are treated equally since the data are based on household information. These data are used both to construct sibling-pairs and in order to generate family characteristics for the OLS specification. The sibling fixed-effects are identified from the identity of the (household) mother. Restricting the analysis to children with identical father and mother reduces the sample somewhat through the exclusion of graduates from single-mother households but does not affect the estimates significantly.

The observable characteristics of the parents used in the OLS specification captures: Immigration status, Education, Employment, Earnings, Self-employment, Taxed capital income, Disposable income and Welfare assistance. In addition, the regressions OLSregressions include 2000 parish of residence fixed effects in order to capture more of the relevant socio-economic background. An average parish has about 4000 inhabitants. All variables are measured during the graduates last year in high school. ${ }^{10}$

Individual-level demographic variables capture year of birth, gender and country of birth (Swedish, other Nordic county or the rest of the world). The only individual-level control variable dated after the graduation year is a dummy for military service. The Swedish military is based on conscription, and as a result, a large fraction of the males (and very few female volunteers) enter the military at some point in time. The decision on if, when, and how the worker will fulfill his service is usually taken at age 17.we therefore considered it to be exogenously determined.

\footnotetext{
${ }^{10}$ The exception being data on taxed capital income that is taken from the graduation year since data for 1990 where unavailable.
} 
Unemployment and employment. One of the two alternative variables used in order to measure initial labor market status is a dummy for whether the graduate became unemployed during the year following graduation. The unemployment data captures the number of days a worker is registered as unemployed at the public employment service, 11 and a dummy is given the value one if a worker is registered as unemployed for at least 50 days between September and May, and zero otherwise.12 Unemployment in the subsequent years is measured using corresponding definitions. The choice of September to May for the measure of unemployment is based on the assumption that registered unemployment experiences during the summer months are less informative than the rest of year for young workers. The results are robust to changes in the arbitrary cut-off at 50 days in order to be classified as unemployed.

The alternative explanatory variable is employment after graduation. Employment is measured using Statistics Sweden's earnings-based definition which codes workers with earnings corresponding to 4 hours of work in November as employed. The same definition is also used when employment is used as the outcome variable.

In addition to studying the effects on employment and unemployment, we will also study the effects on log annual labor earnings. In the baseline specification observations without earnings are changed to the minimum amount in the data (100 SEK $\approx \$ 15)$ but we also estimate a model conditional on being employed in November, which excludes the zero earnings cases. Labor earnings are measured by calendar-year so the analysis of the effects of initial unemployment on earnings will start two years after graduation since the first year overlaps with the initial unemployment period (see above).

\footnotetext{
${ }^{11}$ We do not include time spent in active labor market programs. Qualitatively, the results are very similar if time spent in labor market programs is treated as unemployment.

${ }^{12}$ Graduation typically takes place in early June.
} 
Aggregate covariates. Aggregate unemployment rates are calculated using the unemployment register matched with a population-wide register of education. A programspecific unemployment-to-population rate (henceforth referred to as "unemployment rate") is calculated for each combination of program, municipality and year using the 50 days May to September procedure explained above. 13 The calculation is based on individuals aged 21 to 35 during the graduation year (i.e. they are 3 to 16 years older than the graduates) in order to get a measure of the labor market conditions relevant for relatively young workers. An overall municipality unemployment rate is also calculated for each year using the same procedure and population but without separating the different programs. Furthermore, all regressions include dummies for graduation year (interacted with birth year) in order to remove effects from aggregate cycles.

\section{$\underline{\text { Descriptive statistics }}$}

Table Al in Appendix A shows descriptive statistics for the main time invariant covariates used in the analysis. Figure 2 show the development over time for unemployment and employment separated by initial labor market performance. It is clear that those unemployed after graduation are unemployed during the following ten years to a much higher degree. It is equally true that those employed after graduation have a higher probability of being employed during the 9 years following graduation.

\section{[Figure 2]}

\footnotetext{
${ }^{13}$ Unique program unemployment rates cannot be calculated for the 3-year vocational programs in the piloting scheme since there are no older graduates. The 2-year programs with corresponding occupations are used instead (see Ekström, 2002, for the correspondences).
} 


\section{SIBLING FIXED EFECTS ESTIMATES}

The descriptive statistics shows a positive correlation between unemployment after graduation and subsequent unemployment. The purpose of this section is to identify causal effects of unemployment subsequent to graduation. The identification strategy uses sibling fixed effects to remove all unobserved heterogeneity that is common within a family. Table 1 shows the raw relationship between the unemployment probabilities of the youngest and the oldest child of each sibling pair. The table shows that youths with older siblings who were unemployed (employed) at a certain time after graduation have 5-10 percentage points higher probability of being unemployed (employed) at the same time after graduation. This fairly strong association between siblings, which imply that the risk of unemployment is nearly 50 percent higher in relative terms if the older sibling also was unemployed, suggests that (potentially unobserved) family background is an important determinant of youth labor market outcomes.

\section{[Table 1]}

The identifying assumption required for the model is that all relevant differences between siblings are captured by the individual level variables. These variables are Gender, Age at graduation (18 or 19, interacted with graduation year), Oldest sibling (dummy), Type of vocational program (dummies), GPA and Field GPA interacted with program dummies, Failed (dummy), in-school employment (dummy) and the log of In-school earnings. Note also that included siblings are quite similar in age (at most 4 years in between the siblings) as well as educational choice and performance since only graduates from vocational programs are included. 
In addition to the individual level variables, the estimated linear probability model also includes two measures of the contemporary labor market conditions in the original municipality. ${ }^{14}$ The first is average unemployment among 15 proceeding cohorts of the same high-school programs (i.e. occupation) for each year and municipality. The second measure is municipality-year average defined over the same population. Table A2 in Appendix A shows estimates for the control variables during some of the outcome years.

Naturally, individuals without siblings in the base sample have to be removed. Table Al in Appendix A shows that the resulting sample is very similar to the overall sample in most characteristics and Section VI below shows that this reduced sample produces similar results as the overall sample when relying on observed characteristics for identification. This should ensure that the results we find are not specific to the sibling sample.

Table 2 shows the estimates of the effects of initial unemployment on future labor market performance. Estimates are only calculated for the 7 years (6 when the outcome is other than unemployment) for which there are 4 full cohorts since the number of sibling pairs drops dramatically if only one cohort is excluded. The effect of post-graduation unemployment is statistically significant for all outcome variables during 5 years after graduation: unemployment is increased by 3 percentage-points and employment is decreased by about 5 percentage points. As a comparison, the estimate is of about the same magnitude as the (raw) difference between youths (at $t=5$ ) depending on the unemployment experience of the older sibling displayed in Table 2. Using employment as the variable measuring initial labor market performance gives a similar picture, results are presented in bottom panel of

\section{Table 2.}

\section{[Table 2]}

\footnotetext{
${ }^{14}$ The reason for conditioning on the original municipality is to avoid controlling for endogenous migration patterns since
} 
The identifying assumption behind the causal interpretation of the estimates is that all relevant differences between siblings are captured by the individual level covariates. In order to get some indication of the importance of heterogeneity within a sibling pair, Figure 3 shows estimates of models with and without the individual level covariates and with and without sibling fixed effects (using the sibling sample and no family background variables in all cases). The results show that the individual level covariates make a large difference without the fixed effects but only a small difference when the sibling fixed effects are included. This is at least an indication that heterogeneity within siblings pairs is of smaller importance than heterogeneity across sibling pairs.

\section{[Figure 3]}

One potential alternative to the sibling fixed effects model is to use aggregate unemployment as an instrument for individual unemployment experiences as proposed by Ellwood (1982) and implemented by Gregg (2001). As long as aggregate unemployment rates are uncorrelated with unobserved individual characteristics, it appears to be a valid instrument. However, experiments with this strategy gave two results: First, the standard errors are too large for the analysis to be informative. Second, the IV-estimates are much larger than the corresponding OLS-estimates. This is in line with the results in Gregg (2001) but seems counterintuitive since the point of the instrument is to remove the upward bias from unobserved heterogeneity. A likely reason is that high (local) unemployment rates not only increases the unemployment probability of the graduates, but also reduces the quality of the jobs found, suggesting that the negative effect of poor aggregate conditions is larger than estimated by the first stage regression which would imply that IV estimates (using

initial unemployment may affect future mobility. 
aggregate unemployment as instruments) of future consequences of early unemployment spells could be upward biased.

\section{Different forms of duration dependence.}

The seminal paper by Heckman and Borjas (1980) defines four different categories of true state dependence: "Markovian dependence" (it takes some time to leave any state), "duration dependence" (exit rates may be declining with time spent in a state), "occurrence dependence" (the number of previous spells may matter in the future), and "lagged duration dependence" (the lengths of previous spells may matter in the future).

While it is difficult to separate the different forms of duration dependence from each other, some tentative conclusions can be drawn. First of all, the spell lengths are too short to explain very long lasting effects, less than a percent of spells lasts more than two years. Thus, the longest lasting "scars" are likely to be driven by effects after the interruption of the initial spell. Thus, Markovian or (pure) duration dependence cannot be the complete story. Furthermore, Table 3 shows estimates where we separate the effects of occurrence and duration of the initial unemployment experience. The results suggest that both lagged occurrence and duration are important in the short run, however, with a "declining marginal effect" of another day of initial unemployment. In the longer run, however, it appears as if the effects of short spells disappears, suggesting that lagged duration dependence is driving the results in the longer perspective. Some caution is warranted though since the estimates are quite imprecise and few of the differences between estimates are significant.

\section{[Table 3]}




\section{SUB SAMPLE OLS-ESTIMATES}

The sibling fixed effects estimates imply significant effects up to five years after graduation and there are some indications of even more long lasting causal effects. The purpose of this section is to study the robustness of the results to different sample restrictions and to study potential heterogeneity in the scarring effects.

Using a sibling fixed effects specification comes with a substantial cost in degrees of freedom: only 10 percent of the sample is used and the average number of individuals per fixed effect is 2.03. Thus, when studying the effects in smaller sub-samples we would rapidly encounter problems with too large standard errors (as an example, restricting the analysis by gender will reduce the sample dramatically since all mixed sibling pairs would be dropped). Instead we use an OLS specification where a rich set of observed socioeconomic family background variables act as a substitute for the sibling fixed effects.

The estimated equations use all available observable family background information (see Section III and Appendix A) instead of the sibling fixed effects. The estimated linear probability model thus includes variables capturing ethnicity, education, employment, selfemployment, earnings, welfare receipts, disposable income and capital income of the parents and geographical location dummies at the parish (sub-municipal) level as well as the individual background characteristics and the two measures of labor market conditions included in the sibling fixed effects specification.

In order to highlight the differences in estimates, Figure 4 displays how the estimates change when we base the identification on observables rather than the sibling fixed effects. Note that the OLS estimates in the figure are based on the siblings-sample in order to isolate the difference in estimates between specifications. The OLS estimates are somewhat larger in magnitude than the sibling fixed effects estimates; the differences are in the order of one 
to two standard errors from the sibling model. The confidence intervals of the OLS estimates (not included in the figure) are much smaller since removing the fixed-effects in practice increases the degrees of freedom by a factor of almost 2 even without changing the sample.

The fact that the OLS specifications generate somewhat larger estimates than the sibling fixed effects specification probably implies that the OLS estimates are upward biased. However, under the implicit assumption that this bias is similar in different sub-samples, we find it worthwhile to use the OLS specification to gain the precision we need for sub-sample analyses to be informative. The idea is that differences between estimates from different sub-samples should be informative even if the estimates themselves are biased.

\section{[Figure 4]}

Table 4 uses the OLS specification to study the effects of teenage unemployment for the for males and females separately. The estimates are very similar for the two genders. It should, however, be noted that most of the occupations catered for by the vocational high school system are dominated by one gender which makes it impossible to rule out the possibility that behavioral differences between males and females are counteracted by differences between occupations. The table also show separate estimates for immigrants and for the 1991-cohort which entered the labor market when conditions were relatively good. Again, the patterns are in all cases consistent with the overall estimates. This finding similar to results found in Biewes and Steffes (2010) who study slightly older German workers and interpret an insignificant interaction effects with the past aggregate unemployment rate as evidence against proposed models of stigma effects. Experiments with other interactions (such as grades) do not indicate any substantial heterogeneity in the effects either. Thus, the overall impression is that the long-run effects of teenage unemployment are quite homogeneous within our sample of young blue collar workers of both genders.

\section{[Table 4]}


Table 4 also shows robustness checks using different sub-samples: ${ }^{15}$ It is shown that the estimates are insensitive to restrictions on the sample by: i) excluding individuals that acquire further education after graduation, ii) only including those that entered the labor force directly after graduation, iii) only including 18 year-old graduates from 2-year vocational programs. It is also shown that the estimated marginal effects from probits are virtually identical to the estimates from the linear probability models. We have also estimated all models in Table 4 using employment to measure initial labor market status, and the results are in all cases compatible (results are available on request).

\section{CONCLUDING REMARKS}

Young workers that enter unemployment exit much faster than older workers which could suggest that youth unemployment is a harmless state requiring little attention from policymakers. However, little is known about the long run effects of early unemployment experiences. Partly this is because separating causal effects of unemployment from unobserved heterogeneity is an intrinsically difficult task.

The results in this paper show that experiences of unemployment subsequent to graduation have negative effects on both unemployment and earnings at least 5 years after graduation. Although the effects are far from trivial in size with an increased risk of unemployment in the order of 3 percentage points after five years, it is also clear that the effect diminishes over time. Thus, the evidence suggests that the effects of teenage unemployment are persistent but not permanent.

It should, however, be noted that it is impossible to rule out with absolute certainty that the effects are contaminated by remaining unobserved factors. Although our data handles all

\footnotetext{
${ }^{15}$ Table A3 in Appendix A shows control variable estimates for some of the outcome years.
} 
(persistent) family factors, many aspects related to the individual such as performance in the work related subjects and in-school work experience, and local occupation specific unemployment rates, some confounding factors may still have been left out. For the skeptical reader, our estimates should in that case be viewed as an upper bound of the true effects since potential confounders by all likelihood should bias the estimates upwards. Thus, the lesson that the effects of early unemployment are unlikely to be permanent holds even if the estimates are upward biased due to left-out confounders.

The results give no direct evidence on the nature or causes of the scarring effects. A few things can however be noted: First, the effects survive long after the completed unemployment spells (since most spells are short). Second, the size of the effects decline over time. Third, there is a short-run effect of both incidence and duration but the effects of shorter spells appear to decline faster over time.

Overall, the estimates presented in this paper suggest a long-lasting, although not permanent, negative causal effect of unemployment at the time of labor market entry implying that policy initiatives to combat youth unemployment may well be worthwhile despite the short average spell-length among young unemployed. More research is however needed in order to define the exact mechanisms behind the results.

The time pattern of the results fit nicely into a story where employers use workers' unemployment history as a screening device when hiring. It seems reasonable that (especially short) spells several years ago either are assumed to contain little information or are not detected in the hiring process. However, the fact that we find similar effects for the cohort who entered before the recession could be interpreted as evidence such an interpretation since employers should view their unemployment periods as more informative regarding unobservable characteristics. Since we know little about how human capital behaves during career interruptions it is difficult to say whether or not the results could be 
generated by skill-loss. However, since the effects do not appear to be permanent, it has to be the case that time compensates for lost skills (in particular for skills lost during short spells) if skill-loss is the explanation. ${ }^{16}$

\footnotetext{
${ }^{16}$ Seniority rules, on the other hand, are not likely to be a key determinant of these particular results since none of the workers included in the study had any tenure to lose before becoming unemployed.
} 


\section{References}

Agell J and H Bennmarker (2002) "Wage incentives and wage rigidity: A representative view from within" Labour Economics 14(3) pp 347-369.

Arulampalam W (2001) "Is Unemployment Really Scarring? Effects of Unemployment Experiences on Wages" Economic Journal 111 pp 585-606.

Arulampalam W (2002) "State dependence in Unemployment Incidence" Evidence for British Men Revisited" IZA Discussion paper 630.

Arulampalam W, Booth A L and M P Taylor (2000) "Unemployment Persistence" Oxford Economic Papers 52, pp 24-50.

Åslund O and D-O Rooth (2007) "Do when and where matter? Initial labor market conditions and immigrant earnings" Economic Journal 117(518) pp 422-448.

Beadry P and J DiNardo (1991) "The Effect of Implicit Contracts on the Movement of Wages over the Business Cycle: Evidence from Micro Data" Journal of Political Economy, vol 99, no 4, pp $655-88$.

Biewen M and S Steffens (2010) "Unemployment Persistence: Is there evidence for stigma effects?" Economics Letters 106(3) pp 188-190.

Bound J and Solon G (1999) "Double trouble: on the value of twins-based estimation of the return to schooling" Economics of Education Review 18, pp 169-182.

Burgess S, Propper C, Rees H and A Shearer (2003) "The Class of 1981: the effects of early career unemployment on subsequent unemployment experiences" Labor Economics 10, pp 291-309.

Clark A, Gorgellis Y and P Sanfey (2001) "Scarring: The Psychological Impact of Past Unemployment" Economica 68, pp 221-41.

Corcoran M (1982) The Employment and Wage Consequences of Teenage Women's Nonemployment" in Freeman R B and D A Wise (Eds.) The youth Labor Market Problem: Its Nature Causes and Consequences, Chicago, University of Chicago Press, pp 391-419

Edin P-A and M Gustavsson (2008) "Time Out of Work and Skill Depreciation" Industrial and Labor Relations Review, vol 61(2), pp163-180.

Eliason M and D Storrie (2006) "Lasting or Latent Scars? Swedish Evidence on the Long-Term Effects of Job Displacement” Journal of Labor Economics, 24(4), pp 831-56

Ellwood (1982) Teenage Unemployment: Permanent Scars or Temporary Blemishes” in Freeman R B and D A Wise (Eds.) The youth Labor Market Problem: Its Nature Causes and Consequences, Chicago, University of Chicago Press, pp 349-390.

Eriksson S and J Lagerström (2006) "Competition between employed and unemployed job applicants: Swedish evidence" Scandinavian Journal of Economics 108(3), pp 373-396. 
Gregg P (2001) "The Impact of Youth Unemployment on Adult Unemployment in the NCDS" Economic Journal 111 pp 626-653.

Gregg P and E Tominey (2005) "The wage scar from male youth unemployment" Labour Economics vol 12(4) pp 487-509.

Gregory M and R Jukes (2001) "Unemployment and Subsequent Earnings: Estimating Scarring among British Men 1984-1994” Economic Journal 111 pp 607-625.

Grilliches Z (1979) "Sibling models and data in economics: Beginnings of a survey" Journal of Political Economy 87(5), pp S37-S64.

Häkkinen I, (2006), “Working While Enrolled in a University: Does it Pay?" Labor Economics 13(2), pp 167-189.

Hansen J and M Lofstrom (2003) "Immigrant Assimilation and Welfare Participation: Do immigrants Assimilate Into or Out of Welfare?” Journal of Human Resources 38(1) pp74-98.

Hämäläinen K (2003) "Education and Unemployment: State dependence in Unemployment among Young People in the 1990s" VATT-discussion papers 312.

Heckman J J and G Borjas (1980) "Does Unemployment Cause Future Unemployment? Definitions, Questions and Answers from a Continuous Time Model of Heterogeneity and State Dependence" Economica 47, pp 247-283.

Jacobson, L, R Lalonde and D Sullivan (1993) "Earnings Losses of Displaced Workers" American Economic Review, 83(4): 685-709.

Knights S, Harris M B and J Loundes (2002) "Dynamic Relationship in the Australian Labor Market: Heterogeneity and State Dependence" Economic Record, Vol 78, No 242, pp 284-98.

Kolm A-S (2005), “Work Norms and Unemployment” Economics Letters 88(3), pp 426-431.

Mroz T A and T H Savage (2006) "The Long-Term Effects of Youth Unemployment".Journal of Human Resources 41(2), pp 259-293.

Muhleisen M and Zimmerman K F (1994) "New Patterns of Labor Mobility: A panel analysis of job changes and unemployment" European Economic Review 38, pp 793-801.

Pissarides C (2000) Equilibrium Unemployment Theory $2^{\text {nd }}$ ed. MIT Press, Cambridge Massachusetts.

Ridder G and G J van den Berg (2003), "Measuring Labor Market Frictions: A Cross-Country Comparison" Journal of the European Economic Association 1(1) pp 224-244.

Stutzer A and R Lalive (2004) "The Role of Social Work Norms in Job Searching and Subjective Well-Being” Journal of the European Economic Association, vol 2(4), 696-719.

von Wachter T (2009) "Summary of the Literature on Job Displacement in the US and EU: What we know and what we would like to know" in Marsden D and Ryxc F Wage Structures, Employment Adjustments and Globalization: Evidence from Linked and Firm-level Panel Data, Applied Econometrics Association Series, Palgrave Macmillan 


\section{Tables}

Table 1: Labor market performance for sibling-pairs.

\begin{tabular}{l|ccccc}
\hline & \multicolumn{2}{|c}{ Young sibling unemployment } & & \multicolumn{2}{c}{ Young sibling employment } \\
\hline $\begin{array}{l}\text { Time after } \\
\text { graduation }(t)\end{array}$ & $\begin{array}{l}\text { If older sibling } \\
\text { unemployed }\end{array}$ & $\begin{array}{l}\text { If older sibling } \\
\text { not } \text { unemployed }\end{array}$ & & $\begin{array}{l}\text { If older sibling } \\
\text { employed }\end{array}$ & $\begin{array}{l}\text { If older sibling } \\
\text { not } \text { employed. }\end{array}$ \\
$t=0$ & 0.30 & 0.20 & & 0.45 & 0.38 \\
$t=1$ & 0.40 & 0.32 & & 0.57 & 0.46 \\
$t=3$ & 0.35 & 0.26 & & 0.69 & 0.54 \\
$t=5$ & 0.21 & 0.16 & & 0.76 & 0.66 \\
\hline
\end{tabular}

Note: The table shows the unemployment (employment) probability of younger siblings depending on whether the older sibling was unemployed (employed) at the same time after graduation. The "oldest" sibling is randomly chosen if the birth year is the same for both siblings. 
Table 2: The effects of initial unemployment and employment on subsequent labor market performance-sibling fixed effects estimates

\begin{tabular}{|c|c|c|c|c|c|c|}
\hline & \multicolumn{6}{|c|}{ Year after graduation $(t)$} \\
\hline & $t=\overline{1}$ & $t=3$ & $t=4$ & $t=5$ & $t=6$ & $\bar{t}=7$ \\
\hline \multicolumn{7}{|c|}{ Effects of initial unemployment } \\
\hline Unemployment (1/0) & $\begin{array}{c}0.074 * * \\
(0.013)\end{array}$ & $\begin{array}{c}0.037 * * \\
(0.012)\end{array}$ & $\begin{array}{c}0.038^{* *} \\
(0.011)\end{array}$ & $\begin{array}{c}0.031 * * \\
(0.011)\end{array}$ & $\begin{array}{c}0.014 \\
(0.009)\end{array}$ & $\begin{array}{c}0.015 \\
(0.009)\end{array}$ \\
\hline $\begin{array}{l}\text { Days of } \\
\text { Unemployment }\end{array}$ & $\begin{array}{c}11.275^{* *} \\
(1.743)\end{array}$ & $\begin{array}{l}4.544 * * \\
(1.715)\end{array}$ & $\begin{array}{l}4.626 * * \\
(1.476)\end{array}$ & $\begin{array}{c}4.299 * * \\
(1.374)\end{array}$ & $\begin{array}{c}2.085 \\
(1.200)\end{array}$ & $\begin{array}{c}2.139 \\
(1.227)\end{array}$ \\
\hline Employment (1/0) & $\begin{array}{l}-0.027 * \\
(0.013)\end{array}$ & $\begin{array}{c}-0.041^{* *} \\
(0.012)\end{array}$ & $\begin{array}{c}-0.036^{* *} \\
(0.012)\end{array}$ & $\begin{array}{c}-0.047 * * \\
(0.012)\end{array}$ & $\begin{array}{l}-0.004 \\
(0.011)\end{array}$ & -- \\
\hline $\ln ($ Earnings $)$ & -- & $\begin{array}{c}-0.288^{* *} \\
(0.061)\end{array}$ & $\begin{array}{c}-0.245^{* *} \\
(0.061)\end{array}$ & $\begin{array}{c}-0.175^{* *} \\
(0.058)\end{array}$ & $\begin{array}{l}-0.089 \\
(0.058)\end{array}$ & -- \\
\hline Number of cohorts & 4 & 4 & 4 & 4 & 4 & 4 \\
\hline $\mathrm{N}$ & 17978 & 17817 & 17707 & 17611 & 17526 & 17443 \\
\hline & \multicolumn{6}{|c|}{ Effects of initial employment } \\
\hline Employment (1/0) & $\begin{array}{c}0.249 * * \\
(0.011)\end{array}$ & $\begin{array}{c}0.074 * * \\
(0.011)\end{array}$ & $\begin{array}{c}0.034 * * \\
(0.011)\end{array}$ & $\begin{array}{c}0.020 \\
(0.010)\end{array}$ & $\begin{array}{c}0.039 * * \\
(0.010)\end{array}$ & -- \\
\hline $\ln ($ Earnings $)$ & $\begin{array}{l}1.354 * * \\
(0.045)\end{array}$ & $\begin{array}{c}0.289 * * \\
(0.051)\end{array}$ & $\begin{array}{c}0.223 * * \\
(0.052)\end{array}$ & $\begin{array}{l}0.121 * \\
(0.051)\end{array}$ & $\begin{array}{c}0.185^{* *} \\
(0.051)\end{array}$ & -- \\
\hline Unemployment (1/0) & $\begin{array}{c}-0.062 * * \\
(0.012)\end{array}$ & $\begin{array}{c}-0.025^{*} \\
(0.011)\end{array}$ & $\begin{array}{l}-0.016 \\
(0.010)\end{array}$ & $\begin{array}{l}-0.006 \\
(0.009)\end{array}$ & $\begin{array}{c}-0.016^{*} \\
(0.008)\end{array}$ & $\begin{array}{c}-0.012 \\
(0.007)\end{array}$ \\
\hline $\begin{array}{l}\text { Days of } \\
\text { Unemployment }\end{array}$ & $\begin{array}{c}-5.166^{* * *} \\
(1.486)\end{array}$ & $\begin{array}{l}-2.018 \\
(1.458)\end{array}$ & $\begin{array}{l}-1.551 \\
(1.292)\end{array}$ & $\begin{array}{l}-1.087 \\
(1.181)\end{array}$ & $\begin{array}{l}-2.238 * \\
(1.012)\end{array}$ & $\begin{array}{l}-2.999 * * \\
(1.038)\end{array}$ \\
\hline Number of cohorts & 4 & 4 & 4 & 4 & 4 & 4 \\
\hline $\mathrm{N}$ & 17978 & 17817 & 17707 & 17611 & 17526 & 17443 \\
\hline
\end{tabular}

Note: Sample includes all graduates observed with a sibling in the sample. Linear probability estimates of the effect of unemployment/employment subsequent to graduation. Regressions include controls for education (Program, Failed, GPA (by program), Field GPA (by program)), Gender, In-school work (log earnings and working in November), Military service (after graduation and at time $t$ ), program specific municipality unemployment at time $t$, municipality unemployment at time $t$ as well as cohort-birth year interaction dummies. Robust standard errors are in parentheses. *Significant at 5\% level. **Significant at $1 \%$ level. 
Table 3: Effects of different durations of initial unemployment.

\begin{tabular}{|c|c|c|c|c|}
\hline \multirow{2}{*}{$\begin{array}{l}\text { Days of initial un- } \\
\text { employment }(t=0)\end{array}$} & \multicolumn{3}{|c|}{ Effect on unemployment at year $t$} & \multirow{2}{*}{$\begin{array}{c}\text { Fraction of } \\
\text { total }\end{array}$} \\
\hline & $t=1$ & $t=3$ & $t=5$ & \\
\hline 1-20 days & $\begin{array}{c}0.050 * * \\
(0.018)\end{array}$ & $\begin{array}{c}0.024 \\
(0.017)\end{array}$ & $\begin{array}{l}-0.015 \\
(0.014)\end{array}$ & $8.7 \%$ \\
\hline 21-50 days & $\begin{array}{c}0.067 * * \\
(0.017)\end{array}$ & $\begin{array}{c}0.026 \\
(0.015)\end{array}$ & $\begin{array}{c}0.013 \\
(0.013)\end{array}$ & $12.1 \%$ \\
\hline 51-100 days & $\begin{array}{c}0.092 * * \\
(0.016)\end{array}$ & $\begin{array}{c}0.051 * * \\
(0.015)\end{array}$ & $\begin{array}{c}0.035 * * \\
(0.013)\end{array}$ & $13.6 \%$ \\
\hline$>100$ days & $\begin{array}{c}0.102 * * \\
(0.020)\end{array}$ & $\begin{array}{l}0.041 * \\
(0.019)\end{array}$ & $\begin{array}{l}0.033^{*} \\
(0.017)\end{array}$ & $8.3 \%$ \\
\hline
\end{tabular}

Note: Sample includes all graduates observed with a sibling in the sample. Linear probability estimates of the effects of unemployment subsequent to graduation on the probability of being unemployed at least 50 days $t$ years later with separate effects depending on the number of days of initial unemployment. Regressions include sibling fixed effects and controls for education (Program, Failed, GPA (by program), Field GPA (by program)), Gender, In-school work (log earnings and working in November), Military service (after graduation and at time $t$ ), program specific municipality unemployment at time $t$, municipality unemployment at time $t$ as well as cohort-birth year interaction dummies. Standard errors are in parentheses. *Significant at $5 \%$ level. **Significant at $1 \%$ level. 
Table 5: Sub-sample estimates (OLS-specification) - effects of initial unemployment on future unemployment.

\begin{tabular}{|c|c|c|c|c|c|c|}
\hline & $t=1$ & $t=3$ & $t=5$ & $t=7$ & $t=9$ & $\mathrm{~N}(\mathrm{t}=1)$ \\
\hline Full sample & $\begin{array}{c}0.117 * * \\
(0.003)\end{array}$ & $\begin{array}{l}0.056^{* * *} \\
(0.003)\end{array}$ & $\begin{array}{c}0.035^{* *} \\
(0.002)\end{array}$ & $\begin{array}{c}0.026 * * \\
(0.002)\end{array}$ & $\begin{array}{c}0.019 * * \\
(0.002)\end{array}$ & 170,811 \\
\hline Males & $\begin{array}{c}0.121^{* *} \\
(0.004)\end{array}$ & $\begin{array}{c}0.052 * * \\
(0.004)\end{array}$ & $\begin{array}{c}0.035^{* *} \\
(0.003)\end{array}$ & $\begin{array}{c}0.025 * * \\
(0.003)\end{array}$ & $\begin{array}{c}0.018 * * \\
(0.003)\end{array}$ & 96,710 \\
\hline Females & $\begin{array}{c}0.107 * * \\
(0.004)\end{array}$ & $\begin{array}{c}0.060 * * \\
(0.004)\end{array}$ & $\begin{array}{c}0.034 * * \\
(0.003)\end{array}$ & $\begin{array}{c}0.025 * * \\
(0.003)\end{array}$ & $\begin{array}{c}0.019 * * \\
(0.003)\end{array}$ & 74,101 \\
\hline $\begin{array}{l}\text { Immigrants, } \\
1^{\text {st }} \text { or } 2^{\text {nd }} \text { generation }\end{array}$ & $\begin{array}{c}0.113^{* *} \\
(0.005)\end{array}$ & $\begin{array}{c}0.055^{* *} \\
(0.005)\end{array}$ & $\begin{array}{c}0.035^{* *} \\
(0.004)\end{array}$ & $\begin{array}{c}0.028 * * \\
(0.003)\end{array}$ & $\begin{array}{c}0.021 * * \\
(0.004)\end{array}$ & 61,048 \\
\hline 1991-cohort only & $\begin{array}{c}0.140 * * \\
(0.006)\end{array}$ & $\begin{array}{c}0.072 * * \\
(0.006)\end{array}$ & $\begin{array}{c}0.045^{* *} \\
(0.005)\end{array}$ & $\begin{array}{c}0.023 * * \\
(0.004)\end{array}$ & $\begin{array}{c}0.019 * * \\
(0.004)\end{array}$ & 45,205 \\
\hline No tertiary education & $\begin{array}{c}0.114 * * \\
(0.003)\end{array}$ & $\begin{array}{c}0.056 * * \\
(0.003)\end{array}$ & $\begin{array}{c}0.033 * * \\
(0.003)\end{array}$ & $\begin{array}{c}0.026 * * \\
(0.002)\end{array}$ & $\begin{array}{c}0.019 * * \\
(0.003)\end{array}$ & 133,634 \\
\hline $\begin{array}{l}\text { In labor force after } \\
\text { graduation }\end{array}$ & $\begin{array}{c}0.167 * * \\
(0.004)\end{array}$ & $\begin{array}{c}0.087 * * \\
(0.003)\end{array}$ & $\begin{array}{c}0.044 * * \\
(0.003)\end{array}$ & $\begin{array}{c}0.031 * * \\
(0.002)\end{array}$ & $\begin{array}{c}0.020 * * \\
(0.003)\end{array}$ & 91,408 \\
\hline $\begin{array}{l}18 \text { y.o. grad:s from } \\
\text { 2-year voc. prog:s }\end{array}$ & $\begin{array}{l}0.110 * * \\
(0.004)\end{array}$ & $\begin{array}{c}0.053 * * \\
(0.004)\end{array}$ & $\begin{array}{c}0.033 * * \\
(0.003)\end{array}$ & $\begin{array}{l}0.025 * * \\
(0.003)\end{array}$ & $\begin{array}{c}0.015 * * \\
(0.003)\end{array}$ & 90,518 \\
\hline Sibling sample & $\begin{array}{c}0.098^{* * *} \\
(0.010)\end{array}$ & $\begin{array}{c}0.047^{* *} \\
(0.009)\end{array}$ & $\begin{array}{c}0.048^{* *} \\
(0.008)\end{array}$ & $\begin{array}{c}0.023^{* * *} \\
(0.007)\end{array}$ & -- & 17,978 \\
\hline Probit (full sample) & $\begin{array}{c}0.124^{* *} \\
(0.003)\end{array}$ & $\begin{array}{c}0.057^{* *} \\
(0.003)\end{array}$ & $\begin{array}{c}0.032^{* *} \\
(0.002)\end{array}$ & $\begin{array}{c}0.023 * * \\
(0.002)\end{array}$ & $\begin{array}{c}0.016^{* *} \\
(0.002)\end{array}$ & 170,811 \\
\hline $\begin{array}{l}\text { Number of cohorts } \\
\mathrm{N} \text { (full sample) }\end{array}$ & $\begin{array}{c}4 \\
170,811\end{array}$ & $\begin{array}{c}4 \\
169,993\end{array}$ & $\begin{array}{c}4 \\
168,888\end{array}$ & $\begin{array}{c}4 \\
168,036\end{array}$ & $\begin{array}{c}2 \\
90,156\end{array}$ & \\
\hline
\end{tabular}

Note: Linear probability (except for "Probit") estimates of the effects of unemployment after graduation on subsequent unemployment. All regressions include program dummies, birth-year dummies interacted with cohort (except "1991-cohort only") and parish fixed effects (except "Probit") as well as all the controls described in table B1 (GPA and Field-GPA effects are interacted with program dummies). "No tertiary education" sample excludes those who achieved any tertiary education by 2000. "In labor force" only includes observations that are unemployed or employed at $\mathrm{t}=0$. "Sibling sample" only includes those with siblings observed in the sample. "Probit" reports marginal effects. Standard errors are in parentheses. *Significant at $5 \%$ level. **Significant at $1 \%$ level. 


\section{Figures}

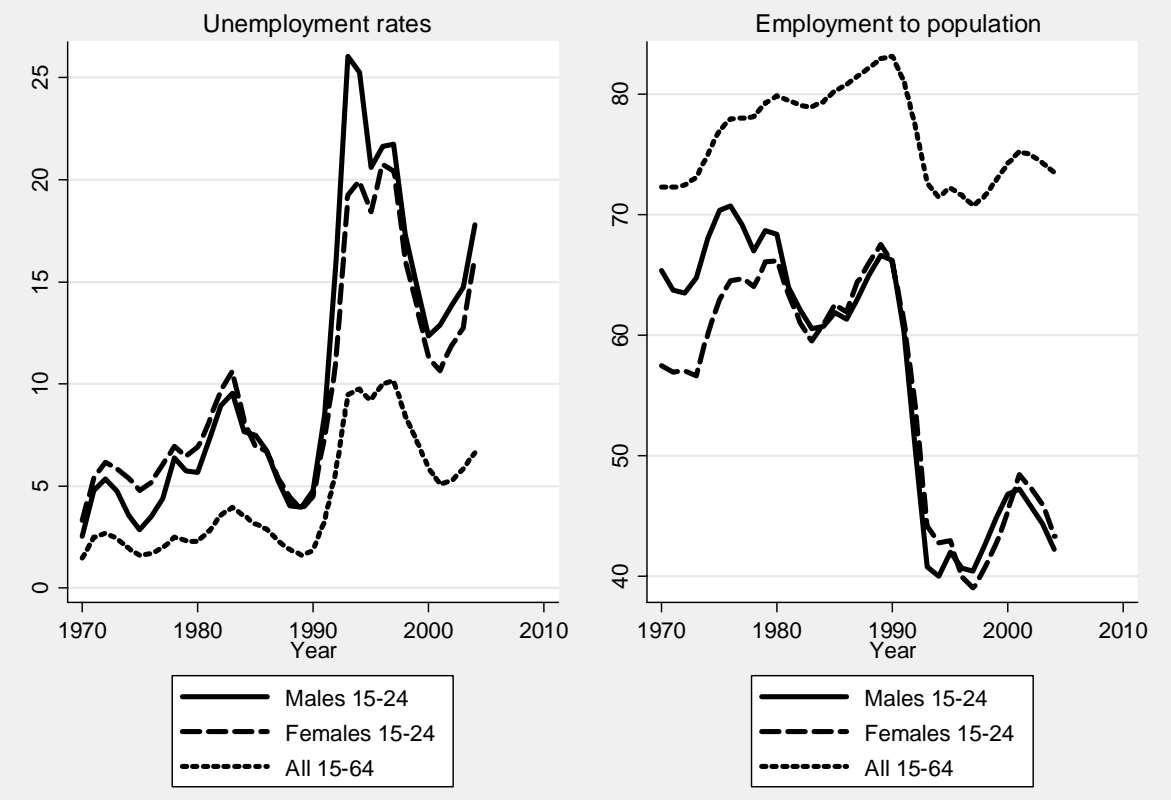

Figure 1 Unemployment and Employment rates according to OECD. 

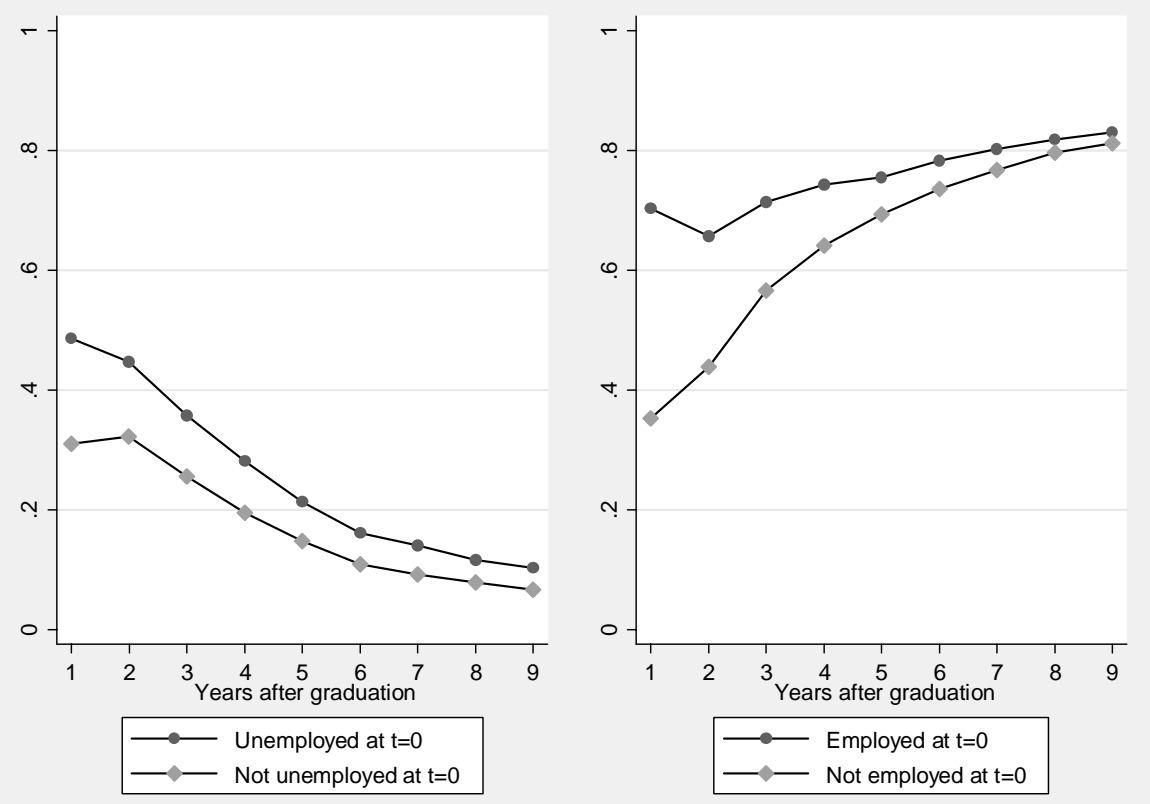

Figure 2 Unemployment and Employment rates depending on post-graduation unemployment and employment. 


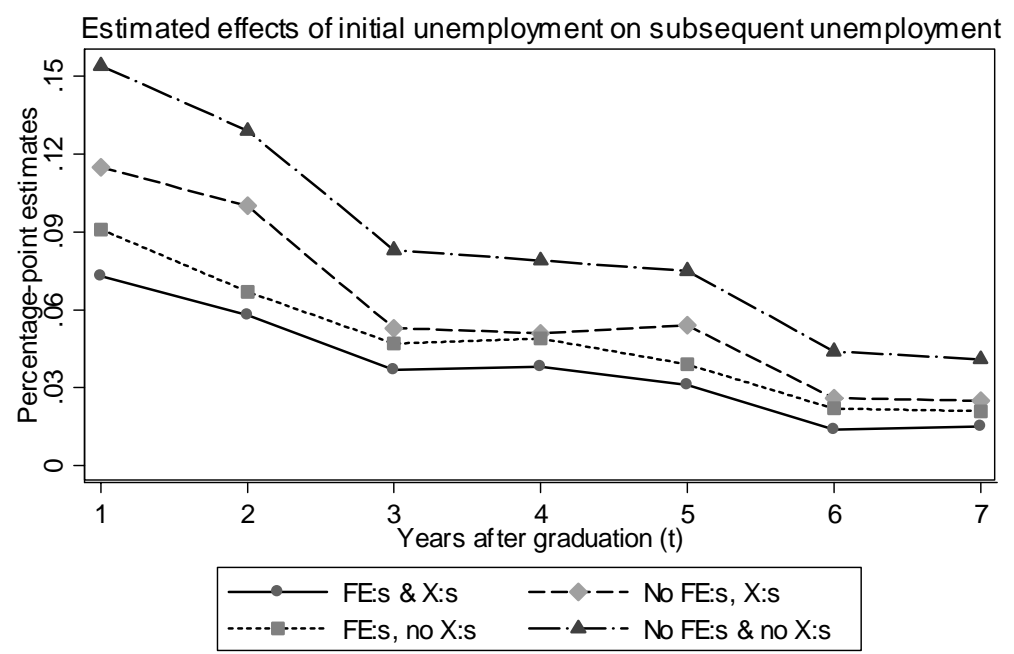

Note: All models include municipality unemployment and year dummies.

Family characteristics not included in X All estimates are significant except 'FE:s \& X:s', $t>5$

Figure 4: Estimates with and without observed individual characteristics $(X)$ and sibling Fixed Effects (FE). 


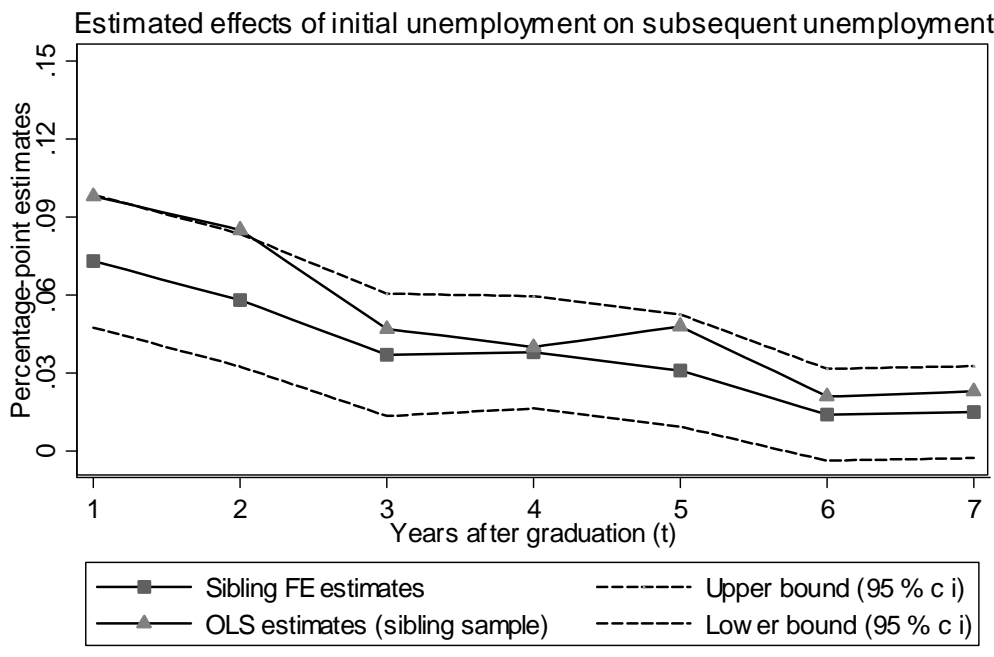

Note: Confidence intervalls are for the sibling FE estimates.

Figure 5: A comparison between Sibling Fixed Effects (FE) estimates and OLS estimates: State dependence in unemployment. 


\section{Appendix A: Covariates}

Table A1: Descriptive statistics

\begin{tabular}{|c|c|c|c|c|}
\hline & Full sample & $\begin{array}{l}\text { Sibling } \\
\text { sample }\end{array}$ & Females & $\begin{array}{c}\text { No tertiary } \\
\text { education }\end{array}$ \\
\hline Failed a course & 0.158 & 0.152 & 0.140 & 0.183 \\
\hline GPA (1-5) & $\begin{array}{c}3.111 \\
(0.614)\end{array}$ & $\begin{array}{c}3.110 \\
(0.607)\end{array}$ & $\begin{array}{c}3.206 \\
(0.608)\end{array}$ & $\begin{array}{c}3.007 \\
(0.589)\end{array}$ \\
\hline Field GPA (1-5) & $\begin{array}{c}3.187 \\
(0.742) \\
\end{array}$ & $\begin{array}{c}3.203 \\
(0.738) \\
\end{array}$ & $\begin{array}{c}3.253 \\
(0.691) \\
\end{array}$ & $\begin{array}{c}3.096 \\
(0.738) \\
\end{array}$ \\
\hline 2-year theoretical & 0.138 & 0.127 & 0.196 & 0.114 \\
\hline 3-year vocational & 0.187 & 0.176 & 0.166 & 0.146 \\
\hline $\begin{array}{l}\text { Male } \\
\text { Graduation age } \\
\text { Mean cohort } \\
\text { Immigrant } \\
\text { Nordic immigrant }\end{array}$ & $\begin{array}{c}0.566 \\
18.4 \\
1992.4 \\
0.042 \\
0.009 \\
\end{array}$ & $\begin{array}{c}0.567 \\
18.3 \\
1992.4 \\
0.050 \\
0.009 \\
\end{array}$ & $\begin{array}{c}-- \\
18.4 \\
1992.4 \\
0.047 \\
0.009 \\
\end{array}$ & $\begin{array}{c}0.593 \\
18.3 \\
1992.4 \\
0.043 \\
0.009 \\
\end{array}$ \\
\hline In-school work (Nov) & 0.194 & 0.201 & 0.226 & 0.190 \\
\hline $\begin{array}{l}\text { In-school earnings (100 } \\
\text { SEK) }\end{array}$ & $\begin{array}{c}103.8 \\
(110.2)\end{array}$ & $\begin{array}{c}106.9 \\
(112.1) \\
\end{array}$ & $\begin{array}{c}106.5 \\
(107.2)\end{array}$ & $\begin{array}{c}100.7 \\
(110.7)\end{array}$ \\
\hline $\begin{array}{l}\text { Ln(Disposable income) } \\
\text { Family on welfare } \\
\text { Self-emp. parent }\end{array}$ & $\begin{array}{c}0.616 \\
(0.385) \\
0.061 \\
0.099 \\
\end{array}$ & $\begin{array}{c}0.542 \\
(0.314) \\
0.083 \\
0.117 \\
\end{array}$ & $\begin{array}{c}0.602 \\
(0.398) \\
0.063 \\
0.089 \\
\end{array}$ & $\begin{array}{c}0.593 \\
(0.381) \\
0.067 \\
0.100 \\
\end{array}$ \\
\hline $\begin{array}{l}\text { Single mother } \\
\text { Single father } \\
\text { Living alone }\end{array}$ & $\begin{array}{l}0.176 \\
0.044 \\
0.030\end{array}$ & $\begin{array}{c}0.140 \\
-- \\
--\end{array}$ & $\begin{array}{l}0.186 \\
0.036 \\
0.043\end{array}$ & $\begin{array}{l}0.182 \\
0.046 \\
0.032\end{array}$ \\
\hline $\begin{array}{l}\text { Mother immigrant } \\
\text { Father immigrant } \\
\text { Both parents imm. }\end{array}$ & $\begin{array}{l}0.169 \\
0.278 \\
0.100 \\
\end{array}$ & $\begin{array}{l}0.107 \\
0.224 \\
0.078 \\
\end{array}$ & $\begin{array}{l}0.170 \\
0.298 \\
0.109 \\
\end{array}$ & $\begin{array}{l}0.177 \\
0.289 \\
0.105 \\
\end{array}$ \\
\hline $\begin{array}{l}\text { Mother working } \\
\text { Father working }\end{array}$ & $\begin{array}{l}0.907 \\
0.894\end{array}$ & $\begin{array}{l}0.902 \\
0.887\end{array}$ & $\begin{array}{l}0.907 \\
0.894\end{array}$ & $\begin{array}{l}0.900 \\
0.887\end{array}$ \\
\hline $\begin{array}{l}\text { Mother's earnings } \\
\quad(100 \text { SEK })\end{array}$ & $\begin{array}{l}1195 \\
(559)\end{array}$ & $\begin{array}{l}1145 \\
(544)\end{array}$ & $\begin{array}{l}1187 \\
(553)\end{array}$ & $\begin{array}{l}1167 \\
(545)\end{array}$ \\
\hline $\begin{array}{l}\text { Father's earnings } \\
\text { (100 SEK) }\end{array}$ & $\begin{array}{l}1874 \\
(921)\end{array}$ & $\begin{array}{l}1805 \\
(885)\end{array}$ & $\begin{array}{l}1871 \\
(917)\end{array}$ & $\begin{array}{l}1815 \\
(867)\end{array}$ \\
\hline $\begin{array}{l}\text { Military service at } t=0 \\
\text { Tertiary education in } \\
2000\end{array}$ & $\begin{array}{l}0.024 \\
0.204 \\
\end{array}$ & $\begin{array}{l}0.022 \\
0.191 \\
\end{array}$ & $\begin{array}{l}0.000 \\
0.251 \\
\end{array}$ & $\begin{array}{c}0.025 \\
-- \\
\end{array}$ \\
\hline $\mathbf{N}$ & 171816 & 17500 & 74598 & 134352 \\
\hline
\end{tabular}

Note: Standard deviations in parentheses. 
Table A2: Control-variable estimates, sibling fixed effects specification.

\begin{tabular}{|c|c|c|c|c|c|c|}
\hline & \multicolumn{3}{|c|}{ Unemployment } & \multicolumn{3}{|c|}{ Employment } \\
\hline & \multicolumn{3}{|c|}{ Year after graduation $(t)$} & \multicolumn{3}{|c|}{ Year after graduation $(t)$} \\
\hline & $t=1$ & $t=3$ & $t=5$ & $t=1$ & $t=3$ & $t=5$ \\
\hline Failed a course & $\begin{array}{l}-0.008 \\
(0.017)\end{array}$ & $\begin{array}{c}0.002 \\
(0.017)\end{array}$ & $\begin{array}{l}0.032 * \\
(0.014)\end{array}$ & $\begin{array}{l}-0.027 \\
(0.016)\end{array}$ & $\begin{array}{c}-0.041^{*} \\
(0.017)\end{array}$ & $\begin{array}{c}-0.067 * * \\
(0.016)\end{array}$ \\
\hline GPA $(1-5)^{1}$ & $\begin{array}{c}-0.051 * * \\
(0.017)\end{array}$ & $\begin{array}{c}-0.051 * * \\
(0.016)\end{array}$ & $\begin{array}{c}-0.038^{* *} \\
(0.013)\end{array}$ & $\begin{array}{l}-0.021 \\
(0.016)\end{array}$ & $\begin{array}{c}-0.054 * * \\
(0.016)\end{array}$ & $\begin{array}{c}-0.035^{*} \\
(0.015)\end{array}$ \\
\hline Field GPA $(1-5)^{1}$ & $\begin{array}{l}-0.022 \\
(0.012)\end{array}$ & $\begin{array}{c}-0.030 * * \\
(0.011)\end{array}$ & $\begin{array}{l}-0.006 \\
(0.01)\end{array}$ & $\begin{array}{c}0.015 \\
(0.012)\end{array}$ & $\begin{array}{c}0.056^{* *} \\
(0.012)\end{array}$ & $\begin{array}{c}0.044 * * \\
(0.011)\end{array}$ \\
\hline Female & $\begin{array}{c}-0.052 * * \\
(0.016)\end{array}$ & $\begin{array}{c}0.009 \\
(0.015)\end{array}$ & $\begin{array}{l}-0.018 \\
(0.013)\end{array}$ & $\begin{array}{l}-0.019 \\
(0.015)\end{array}$ & $\begin{array}{c}0.082 * * \\
(0.015)\end{array}$ & $\begin{array}{c}0.078 * * \\
(0.015)\end{array}$ \\
\hline Oldest sibling & $\begin{array}{l}-0.004 \\
(0.007)\end{array}$ & $\begin{array}{c}0.012 \\
(0.006)\end{array}$ & $\begin{array}{l}-0.006 \\
(0.005)\end{array}$ & $\begin{array}{c}0.004 \\
(0.006)\end{array}$ & $\begin{array}{c}0.001 \\
(0.006)\end{array}$ & $\begin{array}{c}0.007 \\
(0.006)\end{array}$ \\
\hline In-school work (Nov) & $\begin{array}{c}-0.048 * * \\
(0.013)\end{array}$ & $\begin{array}{l}-0.014 \\
(0.013)\end{array}$ & $\begin{array}{l}-0.001 \\
(0.01)\end{array}$ & $\begin{array}{c}0.039 * * \\
(0.013)\end{array}$ & $\begin{array}{c}0.008 \\
(0.013)\end{array}$ & $\begin{array}{c}0.007 \\
(0.012)\end{array}$ \\
\hline $\begin{array}{l}\text { Ln (In-school } \\
\text { earnings) }\end{array}$ & $\begin{array}{l}-0.004 \\
(0.003)\end{array}$ & $\begin{array}{c}-0.009 * * \\
(0.003)\end{array}$ & $\begin{array}{c}0 \\
(0.002)\end{array}$ & $\begin{array}{c}0.012 * * \\
(0.003)\end{array}$ & $\begin{array}{c}0.013 * * \\
(0.003)\end{array}$ & $\begin{array}{c}0.004 \\
(0.003)\end{array}$ \\
\hline $\begin{array}{l}\text { Military service after } \\
\text { graduation }^{2}\end{array}$ & $\begin{array}{l}-0.03 \\
(0.037)\end{array}$ & $\begin{array}{l}-0.002 \\
(0.033)\end{array}$ & $\begin{array}{l}-0.003 \\
(0.029)\end{array}$ & $\begin{array}{c}0.252 * * \\
(0.036)\end{array}$ & $\begin{array}{c}0.054 \\
(0.034)\end{array}$ & $\begin{array}{l}0.070 * \\
(0.029)\end{array}$ \\
\hline Military service at $t$ & $\begin{array}{c}0.085 * * \\
(0.017)\end{array}$ & $\begin{array}{c}0.027 \\
(0.016) \\
\end{array}$ & $\begin{array}{l}-0.031 \\
(0.064)\end{array}$ & $\begin{array}{c}-0.202 * * \\
(0.016)\end{array}$ & $\begin{array}{c}-0.127 * * \\
(0.017)\end{array}$ & $\begin{array}{c}-0.275^{* *} \\
(0.077)\end{array}$ \\
\hline $\begin{array}{l}\ln (\text { Program/municipality } \\
\text { unemployment at } t \text { ) }\end{array}$ & $\begin{array}{l}0.057 * * \\
(0.02)\end{array}$ & $\begin{array}{l}0.036^{*} \\
(0.017)\end{array}$ & $\begin{array}{c}0.024 \\
(0.013)\end{array}$ & $\begin{array}{c}-0.090^{* *} \\
(0.019)\end{array}$ & $\begin{array}{l}-0.022 \\
(0.018)\end{array}$ & $\begin{array}{l}-0.002 \\
(0.015)\end{array}$ \\
\hline $\begin{array}{l}\ln \text { (Municipality } \\
\text { unemployment at } t \text { ) }\end{array}$ & $\begin{array}{c}0.084 \\
(0.056)\end{array}$ & $\begin{array}{c}0.118^{*} \\
(0.05)\end{array}$ & $\begin{array}{l}-0.023 \\
(0.037)\end{array}$ & $\begin{array}{l}-0.105 \\
(0.056)\end{array}$ & $\begin{array}{l}-0.011 \\
(0.052)\end{array}$ & $\begin{array}{c}0.047 \\
(0.044)\end{array}$ \\
\hline $\begin{array}{l}\text { Number of cohorts } \\
\mathbf{N}\end{array}$ & $\begin{array}{c}4 \\
17990\end{array}$ & $\begin{array}{c}4 \\
17830\end{array}$ & $\begin{array}{c}4 \\
17623\end{array}$ & $\begin{array}{c}4 \\
17990\end{array}$ & $\begin{array}{c}4 \\
17830\end{array}$ & $\begin{array}{c}4 \\
17623\end{array}$ \\
\hline
\end{tabular}

Note: All regressions include program dummies, cohort birth-year interaction dummies and municipality fixed effects as well as unemployment/employment subsequent to graduation. ${ }^{1} \mathrm{GPA}$ is interacted with program in all main regressions. ${ }^{2}$ Applies to less than $2 \%$ of the sample. Standard errors are in parentheses. *Significant at $5 \%$ level. **Significant at $1 \%$ level. 
Table A3: Control-variable estimates, OLS-specification (full sample)

\begin{tabular}{|c|c|c|c|c|c|c|}
\hline & \multicolumn{2}{|c|}{$\overline{\text { Year after graduation }(t)}$} & $\frac{n t}{\operatorname{tion}(t)}$ & \multicolumn{3}{|c|}{$\overline{\text { Year after graduation }(t)}$} \\
\hline & $t=1$ & $t=3$ & $t=7$ & $t=1$ & $t=3$ & $t=7$ \\
\hline Failed a course & $\begin{array}{c}0.003 \\
(0.004)\end{array}$ & $\begin{array}{c}0.013^{* *} \\
(0.004)\end{array}$ & $\begin{array}{c}0.024 * * \\
(0.003)\end{array}$ & $\begin{array}{c}-0.049 * * \\
(0.004)\end{array}$ & $\begin{array}{c}-0.074 * * \\
(0.004)\end{array}$ & $\begin{array}{c}-0.051 * * \\
(0.004)\end{array}$ \\
\hline $\operatorname{GPA}(1-5)^{1}$ & $\begin{array}{c}-0.053 * * \\
(0.004)\end{array}$ & $\begin{array}{c}-0.033 * * \\
(0.003)\end{array}$ & $\begin{array}{c}-0.008 * * \\
(0.002)\end{array}$ & $\begin{array}{c}-0.050 * * \\
(0.003)\end{array}$ & $\begin{array}{c}-0.059 * * \\
(0.004)\end{array}$ & $\begin{array}{c}-0.039 * * \\
(0.003)\end{array}$ \\
\hline Field GPA $(1-5)^{1}$ & $\begin{array}{c}-0.040 * * \\
(0.003)\end{array}$ & $\begin{array}{c}-0.047 * * \\
(0.003)\end{array}$ & $\begin{array}{c}-0.026 * * \\
(0.002)\end{array}$ & $\begin{array}{c}0.041 * * \\
(0.003)\end{array}$ & $\begin{array}{c}0.061 * * \\
(0.003)\end{array}$ & $\begin{array}{c}0.050 * * \\
(0.003)\end{array}$ \\
\hline Female & $\begin{array}{c}0.064 * * \\
(0.003)\end{array}$ & $\begin{array}{c}0.013^{* *} \\
(0.003)\end{array}$ & $\begin{array}{c}0.002 \\
(0.002)\end{array}$ & $\begin{array}{c}0.028^{* *} \\
(0.003)\end{array}$ & $\begin{array}{c}-0.052 * * \\
(0.003)\end{array}$ & $\begin{array}{c}-0.065^{* *} \\
(0.003)\end{array}$ \\
\hline Immigrant & $\begin{array}{l}-0.003 \\
(0.007)\end{array}$ & $\begin{array}{c}0.025^{* *} \\
(0.007)\end{array}$ & $\begin{array}{c}0.022 * * \\
(0.005)\end{array}$ & $\begin{array}{c}-0.062 * * \\
(0.006)\end{array}$ & $\begin{array}{c}-0.082 * * \\
(0.007)\end{array}$ & $\begin{array}{c}-0.056^{* *} \\
(0.008)\end{array}$ \\
\hline Nordic immigrant $^{2}$ & $\begin{array}{l}-0.004 \\
(0.014)\end{array}$ & $\begin{array}{l}-0.018 \\
(0.014)\end{array}$ & $\begin{array}{c}-0.030 * * \\
(0.010)\end{array}$ & $\begin{array}{c}0.059 * * \\
(0.013)\end{array}$ & $\begin{array}{c}0.064 * * \\
(0.014)\end{array}$ & $\begin{array}{c}0.042 * * \\
(0.015)\end{array}$ \\
\hline In-school work (Nov) & $\begin{array}{c}-0.023 * * \\
(0.003)\end{array}$ & $\begin{array}{c}-0.016^{* * *} \\
(0.003)\end{array}$ & $\begin{array}{c}-0.006^{* *} \\
(0.002)\end{array}$ & $\begin{array}{c}0.047 * * \\
(0.003)\end{array}$ & $\begin{array}{c}0.019 * * \\
(0.003)\end{array}$ & $\begin{array}{c}0.002 \\
(0.003)\end{array}$ \\
\hline $\begin{array}{l}\text { Ln (In-school } \\
\text { earnings) }\end{array}$ & $\begin{array}{c}-0.013 * * \\
(0.001) \\
\end{array}$ & $\begin{array}{c}-0.012 * * \\
(0.001) \\
\end{array}$ & $\begin{array}{c}-0.006^{* *} * \\
(0.000) \\
\end{array}$ & $\begin{array}{c}0.026 * * \\
(0.001) \\
\end{array}$ & $\begin{array}{c}0.022 * * \\
(0.001) \\
\end{array}$ & $\begin{array}{c}0.012 * * \\
(0.001) \\
\end{array}$ \\
\hline Disposable income & $\begin{array}{l}-0.007 \\
(0.004)\end{array}$ & $\begin{array}{c}-0.021 * * \\
(0.004)\end{array}$ & $\begin{array}{c}-0.008 * * \\
(0.003)\end{array}$ & $\begin{array}{c}0.023 * * \\
(0.004)\end{array}$ & $\begin{array}{c}0.032 * * \\
(0.004)\end{array}$ & $\begin{array}{c}0.017 * * \\
(0.004)\end{array}$ \\
\hline Family on welfare & $\begin{array}{c}0.027 * * \\
(0.005)\end{array}$ & $\begin{array}{c}0.027 * * \\
(0.005)\end{array}$ & $\begin{array}{c}0.019 * * \\
(0.004)\end{array}$ & $\begin{array}{c}-0.032 * * \\
(0.005)\end{array}$ & $\begin{array}{c}-0.056^{* *} \\
(0.005)\end{array}$ & $\begin{array}{c}-0.038 * * \\
(0.006)\end{array}$ \\
\hline $\begin{array}{l}\text { Family's capital } \\
\text { income }\end{array}$ & $\begin{array}{l}-0.585 \\
(1.003)\end{array}$ & $\begin{array}{l}-1.370 \\
(0.732)\end{array}$ & $\begin{array}{c}-0.955^{* *} \\
(0.345)\end{array}$ & $\begin{array}{l}-0.300 \\
(0.611)\end{array}$ & $\begin{array}{l}-0.604 \\
(0.940)\end{array}$ & $\begin{array}{l}-0.419 \\
(0.725)\end{array}$ \\
\hline Self-employed parent & $\begin{array}{c}-0.031 * * \\
(0.004) \\
\end{array}$ & $\begin{array}{c}-0.029 * * \\
(0.004) \\
\end{array}$ & $\begin{array}{c}-0.017 * * \\
(0.003) \\
\end{array}$ & $\begin{array}{c}0.028 * * \\
(0.004) \\
\end{array}$ & $\begin{array}{c}0.033 * * \\
(0.004) \\
\end{array}$ & $\begin{array}{c}0.016 * * \\
(0.004) \\
\end{array}$ \\
\hline $\begin{array}{l}\text { Living with single } \\
\text { mother }\end{array}$ & $\begin{array}{l}-0.002 \\
(0.007)\end{array}$ & $\begin{array}{c}0.004 \\
(0.007)\end{array}$ & $\begin{array}{l}-0.009 \\
(0.005)\end{array}$ & $\begin{array}{c}0.001 \\
(0.007)\end{array}$ & $\begin{array}{c}0.005 \\
(0.007)\end{array}$ & $\begin{array}{l}-0.001 \\
(0.008)\end{array}$ \\
\hline $\begin{array}{l}\text { Living with single } \\
\text { father }\end{array}$ & $\begin{array}{c}-0.023 * \\
(0.009)\end{array}$ & $\begin{array}{l}-0.002 \\
(0.009)\end{array}$ & $\begin{array}{c}-0.019 * * \\
(0.006)\end{array}$ & $\begin{array}{c}0.033 * * \\
(0.009)\end{array}$ & $\begin{array}{c}0.038 * * \\
(0.009)\end{array}$ & $\begin{array}{l}0.024 * \\
(0.009)\end{array}$ \\
\hline Living alone $^{2}$ & $\begin{array}{c}-0.059 * * \\
(0.011)\end{array}$ & $\begin{array}{c}-0.042 * * \\
(0.010)\end{array}$ & $\begin{array}{c}-0.044 * * \\
(0.007)\end{array}$ & $\begin{array}{c}0.062 * * \\
(0.010)\end{array}$ & $\begin{array}{c}0.058^{* *} \\
(0.011)\end{array}$ & $\begin{array}{c}0.051^{* *} \\
(0.011)\end{array}$ \\
\hline Mother immigrant & $\begin{array}{c}0.027 * * \\
(0.007)\end{array}$ & $\begin{array}{l}0.013^{*} \\
(0.006)\end{array}$ & $\begin{array}{c}0.022 * * \\
(0.005)\end{array}$ & $\begin{array}{c}-0.019 * * \\
(0.006)\end{array}$ & $\begin{array}{c}-0.028 * * \\
(0.007)\end{array}$ & $\begin{array}{c}-0.028 * * \\
(0.007)\end{array}$ \\
\hline Father immigrant & $\begin{array}{c}0.025 * * \\
(0.006)\end{array}$ & $\begin{array}{l}0.014^{*} \\
(0.006)\end{array}$ & $\begin{array}{c}0.015^{* *} \\
(0.004)\end{array}$ & $\begin{array}{c}-0.014 * \\
(0.006)\end{array}$ & $\begin{array}{c}-0.026 * * \\
(0.006)\end{array}$ & $\begin{array}{c}-0.018 * * \\
(0.006)\end{array}$ \\
\hline $\begin{array}{l}\text { Both parents } \\
\text { immigrants }\end{array}$ & $\begin{array}{l}-0.003 \\
(0.009)\end{array}$ & $\begin{array}{c}0.008 \\
(0.008)\end{array}$ & $\begin{array}{c}0.001 \\
(0.006)\end{array}$ & $\begin{array}{l}-0.008 \\
(0.008)\end{array}$ & $\begin{array}{l}-0.013 \\
(0.009)\end{array}$ & $\begin{array}{c}-0.01 \\
(0.009)\end{array}$ \\
\hline
\end{tabular}

Note: Table continues on next page (incl. comments). 
Table A3 (Continued)

\begin{tabular}{|c|c|c|c|c|c|c|}
\hline & \multicolumn{3}{|c|}{ Unemployment } & \multicolumn{3}{|c|}{ Employment } \\
\hline & $t=1$ & $t=3$ & $t=7$ & $t=1$ & $t=3$ & $t=7$ \\
\hline Mother working & $\begin{array}{c}0.011 \\
(0.011)\end{array}$ & $\begin{array}{c}0.031 * * \\
(0.011)\end{array}$ & $\begin{array}{c}0.022 * * \\
(0.007)\end{array}$ & $\begin{array}{l}-0.015 \\
(0.010)\end{array}$ & $\begin{array}{c}-0.034 * * \\
(0.011)\end{array}$ & $\begin{array}{l}-0.000 \\
(0.011)\end{array}$ \\
\hline Father working & $\begin{array}{c}0.021 \\
(0.011)\end{array}$ & $\begin{array}{c}0.035^{* *} \\
(0.010)\end{array}$ & $\begin{array}{c}0.005 \\
(0.008)\end{array}$ & $\begin{array}{l}-0.001 \\
(0.011)\end{array}$ & $\begin{array}{l}-0.016 \\
(0.011)\end{array}$ & $\begin{array}{c}-0.026^{*} \\
(0.011)\end{array}$ \\
\hline Ln(Mother's earnings) & $\begin{array}{l}-0.004 * \\
(0.002)\end{array}$ & $\begin{array}{c}-0.006 * * \\
(0.001)\end{array}$ & $\begin{array}{c}-0.004 * * \\
(0.001)\end{array}$ & $\begin{array}{c}0.006 * * \\
(0.001)\end{array}$ & $\begin{array}{c}0.009 * * \\
(0.002)\end{array}$ & $\begin{array}{c}0.006 * * \\
(0.002)\end{array}$ \\
\hline Ln(Father's earnings) & $\begin{array}{l}-0.004^{*} \\
(0.002)\end{array}$ & $\begin{array}{c}-0.005 * * \\
(0.001)\end{array}$ & $\begin{array}{l}-0.002 * \\
(0.001)\end{array}$ & $\begin{array}{c}0.001 \\
(0.001)\end{array}$ & $\begin{array}{l}0.004 * \\
(0.002)\end{array}$ & $\begin{array}{c}0.002 \\
(0.002)\end{array}$ \\
\hline \multicolumn{7}{|l|}{$\begin{array}{l}\text { Mother's education } \\
\text { (ref. 2-year h.s.) }\end{array}$} \\
\hline Compulsory or less & $\begin{array}{c}0.009 * * \\
(0.003)\end{array}$ & $\begin{array}{l}0.006 * \\
(0.003)\end{array}$ & $\begin{array}{c}0.002 \\
(0.002)\end{array}$ & $\begin{array}{l}0.013 * * \\
(0.003)\end{array}$ & $\begin{array}{c}0.009 * * \\
(0.003)\end{array}$ & $\begin{array}{c}0.010 * * \\
(0.003)\end{array}$ \\
\hline 3-year high school & $\begin{array}{c}0.003 \\
(0.005)\end{array}$ & $\begin{array}{l}-0.001 \\
(0.004)\end{array}$ & $\begin{array}{c}0.003 \\
(0.003)\end{array}$ & $\begin{array}{l}-0.009 \\
(0.005)\end{array}$ & $\begin{array}{c}-0.018 * * \\
(0.005)\end{array}$ & $\begin{array}{c}-0.014 * * \\
(0.005)\end{array}$ \\
\hline Some tertiary & $\begin{array}{c}-0.011 * * \\
(0.004)\end{array}$ & $\begin{array}{l}-0.005 \\
(0.004)\end{array}$ & $\begin{array}{c}0.002 \\
(0.003)\end{array}$ & $\begin{array}{c}-0.026 * * \\
(0.004)\end{array}$ & $\begin{array}{c}-0.040 * * \\
(0.004)\end{array}$ & $\begin{array}{c}-0.032 * * \\
(0.004)\end{array}$ \\
\hline 3 -year tertiary or more & $\begin{array}{c}-0.016 * * \\
(0.005) \\
\end{array}$ & $\begin{array}{l}-0.009 \\
(0.005) \\
\end{array}$ & $\begin{array}{l}0.008^{*} \\
(0.003) \\
\end{array}$ & $\begin{array}{c}-0.050 * * \\
(0.005) \\
\end{array}$ & $\begin{array}{c}-0.069 * * \\
(0.005) \\
\end{array}$ & $\begin{array}{c}-0.057 * * \\
(0.006) \\
\end{array}$ \\
\hline \multicolumn{7}{|l|}{$\begin{array}{l}\text { Father's education } \\
\text { (ref. 2-year h.s.) }\end{array}$} \\
\hline Compulsory or less & $\begin{array}{c}0.001 \\
(0.003)\end{array}$ & $\begin{array}{c}-0.007 * \\
(0.003)\end{array}$ & $\begin{array}{c}0.000 \\
(0.002)\end{array}$ & $\begin{array}{c}0.009 * * \\
(0.003)\end{array}$ & $\begin{array}{c}0.013 * * \\
(0.003)\end{array}$ & $\begin{array}{c}0.008 * * \\
(0.003)\end{array}$ \\
\hline 3-year high school & $\begin{array}{l}-0.008^{*} \\
(0.004)\end{array}$ & $\begin{array}{l}-0.004 \\
(0.004)\end{array}$ & $\begin{array}{c}0.007 * * \\
(0.003)\end{array}$ & $\begin{array}{c}-0.016^{* *} \\
(0.004)\end{array}$ & $\begin{array}{c}-0.019 * * \\
(0.004)\end{array}$ & $\begin{array}{c}-0.012 * * \\
(0.004)\end{array}$ \\
\hline Some tertiary & $\begin{array}{c}-0.013^{* *} \\
(0.005)\end{array}$ & $\begin{array}{l}-0.009 \\
(0.005)\end{array}$ & $\begin{array}{c}0.004 \\
(0.003)\end{array}$ & $\begin{array}{c}-0.030 * * \\
(0.005)\end{array}$ & $\begin{array}{c}-0.032 * * \\
(0.005)\end{array}$ & $\begin{array}{c}-0.023 * * \\
(0.005)\end{array}$ \\
\hline 3 -year tertiary or more & $\begin{array}{l}-0.006 \\
(0.006)\end{array}$ & $\begin{array}{l}-0.006 \\
(0.005) \\
\end{array}$ & $\begin{array}{c}0.006 \\
(0.004)\end{array}$ & $\begin{array}{c}-0.050 * * \\
(0.006)\end{array}$ & $\begin{array}{c}-0.086 * * \\
(0.006)\end{array}$ & $\begin{array}{c}-0.057 * * \\
(0.006)\end{array}$ \\
\hline $\begin{array}{l}\text { Military service after } \\
\text { graduation }^{2}\end{array}$ & $\begin{array}{c}-0.021 * * \\
(0.008)\end{array}$ & $\begin{array}{l}-0.015^{*} \\
(0.007)\end{array}$ & $\begin{array}{l}-0.004 \\
(0.005)\end{array}$ & $\begin{array}{c}0.247 * * \\
(0.008)\end{array}$ & $\begin{array}{c}0.050^{* *} \\
(0.007)\end{array}$ & $\begin{array}{l}0.024 * * \\
(0.008)\end{array}$ \\
\hline Military service at $t$ & $\begin{array}{c}0.075^{* *} \\
(0.004)\end{array}$ & $\begin{array}{c}0.039 * * \\
(0.004)\end{array}$ & $\begin{array}{l}-0.019 \\
(0.026)\end{array}$ & $\begin{array}{c}-0.176 * * \\
(0.004)\end{array}$ & $\begin{array}{c}-0.129 * * \\
(0.004)\end{array}$ & $\begin{array}{c}-0.284 * * \\
(0.050)\end{array}$ \\
\hline $\begin{array}{l}\ln \text { (Program/municipality } \\
\text { unemployment at } t \text { ) }\end{array}$ & $\begin{array}{c}0.067 * * \\
(0.005)\end{array}$ & $\begin{array}{l}0.051 * * \\
(0.004)\end{array}$ & $\begin{array}{c}0.017 * * \\
(0.002)\end{array}$ & $\begin{array}{c}-0.068 * * \\
(0.005)\end{array}$ & $\begin{array}{c}-0.047 * * \\
(0.004)\end{array}$ & $\begin{array}{l}-0.008 * \\
(0.003)\end{array}$ \\
\hline $\begin{array}{l}\ln \text { (Municipality } \\
\text { unemployment at } t \text { ) }\end{array}$ & $\begin{array}{c}0.095^{* *} \\
(0.016)\end{array}$ & $\begin{array}{c}0.090 * * \\
(0.015)\end{array}$ & $\begin{array}{c}0.004 \\
(0.007)\end{array}$ & $\begin{array}{c}-0.065 * * \\
(0.016)\end{array}$ & $\begin{array}{c}-0.047 * * \\
(0.016)\end{array}$ & $\begin{array}{c}0.016 \\
(0.012)\end{array}$ \\
\hline $\begin{array}{l}\text { Number of cohorts } \\
\mathbf{N}\end{array}$ & $\begin{array}{c}4 \\
170,811\end{array}$ & $\begin{array}{c}4 \\
169,993\end{array}$ & $\begin{array}{c}4 \\
168,036\end{array}$ & $\begin{array}{c}4 \\
170,811\end{array}$ & $\begin{array}{c}4 \\
169,993\end{array}$ & $\begin{array}{c}3 \\
133,954\end{array}$ \\
\hline
\end{tabular}

Note: All regressions include program dummies, cohort birth-year interaction dummies and municipality fixed effects as well as unemployment/employment subsequent to graduation. ${ }^{1} \mathrm{GPA}$ is interacted with program in all main regressions. ${ }^{2}$ Applies to less than $2 \%$ of the sample. Standard errors are in parentheses. *Significant at $5 \%$ level. **Significant at $1 \%$ level. 